\title{
PEMBARUAN HUKUM KELUARGA DI DUNIA ISLAM (Analisis Terhadap Regulasi Poligami dan Keberanjakannya dari Fikih)
}

\author{
Toha Andiko \\ Fakultas Syariah IAIN Bengkulu \\ JI. Raden Fatah Pagar Dewa Bengkulu \\ Email: toha.andiko@gmail.com
}

\begin{abstract}
This paper explains the regulation of polygamy in five Islamic countries, especially about the causes of their ability and prohibition. The method commonly used for family law reform in these five countries seems to be more dominant using extra-doctrinal reform methods and little with intra-docrinal reform, and even then each with different modifications and pressures. Vertically, the progress of family law in the five countries above from the fiqh books of the school is quite high. The highest is Iran, followed by Malaysia, then Somalia, and finally Indonesia. The more detailed and the many reasons mentioned for the ability of polygamy because of the condition of the wife, means the more loose and the greater the chance of polygamy. Whereas Tunisia absolutely prohibits polygamy.
\end{abstract}

Keywords: family law reform, polygamy reasons

\begin{abstract}
Abstrak: Tulisan ini menjelaskan regulasi poligami di lima negara Islam, khususnya tentang sebab-sebab kebolehan dan pelarangannya. Metode yang umum digunakan untuk pembaruan hukum keluarga di lima negara tersebut, tampaknya lebih dominan menggunakan metode extra-doctrinal reform dan sedikit dengan intra-docrinal reform, itupun masingmasing dengan modifikasi dan tekanan yang berbeda-beda. Secara vertikal, keberanjakan hukum keluarga pada kelima negara di atas dari kitab-kitab fikih mazhab cukup tinggi. Yang tertinggi adalah Iran, disusul Malaysia, lalu Somalia, dan terakhir Indonesia. Semakin rinci dan banyak sebab yang disebutkan untuk kebolehan poligami karena keadaan istri, berarti semakin longgar dan besar peluang poligami. Sedangkan Tunisia melarang poligami secara mutlak.
\end{abstract}

Kata kunci: pembaruan hukum keluarga, sebab poligami

\section{Pendahuluan}

Dalam penelitian mengenai pembaharuan hukum Islam di negara-negara Islam, J.N.D Anderson dan John L.Esposito ${ }^{1}$ berkesimpulan bahwa metode yang umumnya dikembangkan oleh para pembaharu Islam dalam menangani isu-isu hukum masih bertumpu pada pendekatan yang ad hoc dan terpilah-pilah dengan menggunakan prinsip takhayyur ${ }^{2}$ dan talfiq. ${ }^{3}$

1 J.N.D. Anderson, Law Reform in the Muslim World, (London: University of London the Athlon press, 1976), h. 42 dan John L.Esposito, Women in Muslim Family Law, (Syracus: Syracus University Press, 1982), h. 94-102.

2 Takhayyur adalah suatu metode yurisprudensi yang karena dalam situasi spesifik dibolehkan meninggalkan mazhab hukumnya untuk mengikuti mazhab lainnya, Anderson, J.N.D. Anderson, Law Reform..., h. 51.

${ }^{3}$ Talfiq adalah suatu metode mengkombinasikan berbagai
Dalam perspektif sejarah, pembaharuan hukum Islam menurut Noel J. Coulson menampakkan diri dalam empat bentuk: Pertama, dikodifikasikannya (pengelompokan hukum yang sejenis ke dalam kitab undang-undang) hukum Islam menjadi perundang-undangan negara, yang disebut sebagai doktrin siyasah. Kedua, tidak terikatnya umat Islam pada hanya satu mazhab hukum tertentu, yang disebutnya doktrin takhayyur (seleksi) pendapat mana yang paling dominan dalam masyarakat. Ketiga, perkembangan hukum dalam mengantisipasi perkembangan peristiwa hukum yang baru timbul, yang disebut doktrin tathbiq (penerapan hukum

mazhab untuk membentuk peraturan tunggal. J.N.D. Anderson, Law Reform..., h. 55. 
terhadap peristiwa baru). Keempat, perubahan hukum dari yang lama kepada yang baru yang disebutnya doktrin tajdid (reinterpretasi). ${ }^{4}$

Adanya tantangan yang kompleks di era modern ini telah mendorong para pembaharu untuk melakukan reformasi hukum. Anderson mengemukakan bahwa ada dua pola reformasi hukum di dunia Islam. Pertama, syari'at lambat laun semakin terabaikan dari kehidupan sehari-hari seperti hukum dagang, pidana, dan lainnya untuk kemudian mengikuti "hukum asing." Kedua, hukum keluarga yang dianggap sakral akan mengalami perubahan signifikan dengan jalan interpretasi ulang. ${ }^{5}$

Upaya untuk melaksanakan hukum Islam yang paling menonjol adalah dalam bidang hukum keluarga, karena ia merupakan poros Syari'ah ${ }^{6}$ serta dianggap sebagai tolok ukur terlaksana dan diakui atau tidak hukum Islam di suatu negara.

Di antara topik reformasi hukum keluarga di negara-negara muslim ialah masalah poligami dengan aturan yang sedemikian rupa, mulai dari yang melarang, membatasi, mempersempit ruang gerak poligami, hingga yang membolehkan dengan syarat yang longgar. Namun yang menarik bagi penulis adalah pengaturan tentang alasan-alasan poligami karena keadaan istri yang tampaknya dalam kitab-kitab fikih tidak pernah dibahas secara khusus dan mendetil. Oleh sebab itu pembahasan tulisan ini tidak melebar pada syarat yang harus dipenuhi oleh suami, seperti keadilan dan kemampuan ekonomi. Kalaupun ada disebutkan sekilas hanyalah sekedar pelengkap untuk pengayaan informasi sekaligus menepis kesan diskriminatif.

\section{Poligami Dalam Fikih}

Dalam Alquran maupun hadis-hadis Nabi tidak ditemukan secara eksplisit ketentuan yang mengatur alasan poligami karena keadaan istri. Ayat-ayat Alquran yang berbicara masalah poligami, misalnya surat al-Nisa' ayat 3 :

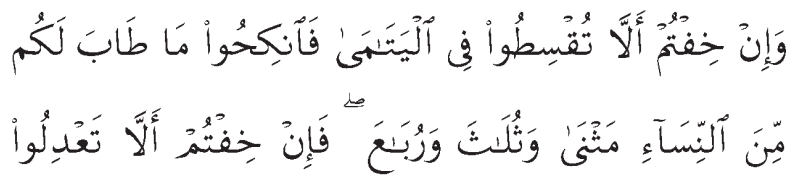

4 N.J. Coulson, A History of Islamic Law, (Edinburgh: Edinburgh University Press, 1994), h. 149-185.

${ }^{5}$ J.N.D. Anderson, J.N.D. Anderson, Law Reform..., h. 1-2

${ }^{6}$ John L.Esposito, Women in Muslim..., h. X

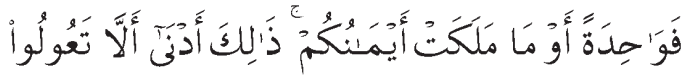

"Dan jika kamu khawatir tidak akan dapat berlaku adil terhadap hak-hak perempuan yatim (bila kamu mengawininya), maka kawinilah perempuanpeempuan lain yang kamu senangi dua, tiga, atau empat orang. Kemudian jika kamu khawatir tidak akan dapat berlaku adil, maka (kawinilah) seorang saja, atau budak-budak yang kamu miliki. Yang demikian itu adalah lebih dekat kepada tidak berbuat aniaya" (Al-Nisa[4]: 3)

Ayat di atas menyebutkan kebolehan poligami yang dilakukan jika diperlukan (karena khawatir tidak akan berlaku adil terhadap anak-anak yatim) dengan syarat yang cukup berat yaitu keadilan yang bersifat material. Begitu juga dengan surat al-Nisa'ayat 129: "Dan kamu sekali-kali tidak akan dapat berlaku adil di antara istri-istri(mu), walaupun kamu sangat ingin berbuat demikian. .". yang menyatakan ketidakmungkinan manusia untuk bisa berlaku adil (secara immaterial/cinta) walaupun seseorang sangat ingin dan sudah berusaha semaksimal mungkin. Selanjutnya kalau dikaji berdasarkan munasabah ayat dengan melihat ayat-ayat sebelumnya, maka dapat diketahui bahwa surat al-Nisa' ayat 1 berbicara tentang penciptaan laki-laki dan perempuan dari sumber yang sama, karena itu memberikan gambaran kesetaraan kedua jenis kelamin. Lalu al-Nisa' ayat 2 berisi desakan kepada muslim agar memberi harta anak yatim yang menjadi warisannya dan tidak mengganggu untuk kepentingan wali. Kemudian al-Nisa' ayat 3 memberikan alternatif bagi laki-laki (wali) yang khawatir tidak dapat berlaku adil terhadap anakanak yatim tersebut supaya melakukan poligami dengan menikahi selain anak yatim perempuan yang dalam perwaliannya atau ibunya anak-anak yatim. Dengan demikian, penekanan ayat 1, 2, dan 3 surat al-Nisa' di atas tampaknya bukan pada poligami itu sendiri, tapi perintah berbuat adil kepada orang-orang yang memelihara anakanak yatim.

Khusus mengenai sabab al-nuzûl al-Nisa' ayat 3, al-Shabuni mengemukakan bahwa alBukhari meriwayatkan dari Urwah ibn Zubair sesungguhnya ia pernah bertanya kepada Aisyah tentang firman Allah di atas. Lalu Aisyah berkata: Hai anak saudaraku, si yatim ini berada di bawah perwaliannya dan hartanya tercampur menjadi 
satu. Wali itu tertarik pada harta dan kecantikan wajah si yatim, lalu hendak mengawininya. Tetapi cara ini tidak adil mengenai pemberian mahar untuk si yatim, ia tidak memberinya seperti yang diberikan kepada wanita lain. Maka berbuat demikian dilarang, lain halnya kalau ia bisa adil. Padahal mereka terbiasa memberi mahar tinggi. Begitulah lalu mereka disuruh mengawini perempuan yang cocok dengan mereka selain anak yatim itu. ${ }^{7}$

Pendapat senada dikemukakan al-Jasshâs yang menurutnya ayat 3 surat al-Nisa' di atas berkenaan dengan anak yatim yang dinikahi walinya. Bahkan menurut al-Jasshâs, larangan menikahi anak yatim ini begitu kuat. Hal ini terlihat dengan dimasukkannya materi ini pada bab tazwîj al-shighar (pernikahan anak di bawah umur). ${ }^{8}$

Begitu juga dengan al-Thabari yang mengatakan bahwa ayat 3 surat al-Nisa' tersebut terkait erat dengan nasib perempuan dan anak yatim. Menurutnya, di antara pendapat ulama yang mendekati kebenaran adalah pendapat yang mengatakan bahwa makna ayat ini terkait dengan kekhawatiran tiadanya wali yang bisa berbuat adil terhadap anak yatim. Maka kalau demikian, kekhawatiran ini dengan sendirinya berlaku juga pada cara mensikapi wanita. Maka "janganlah berpoligami, kecuali pada wanita yang mungkin kamu bisa berlaku adil (dengan) dua sampai empat orang." Sebaliknya, kalau ada kekhawatiran tidak bisa berlaku adil ketika poligami, maka cukuplah dengan menikahi budak wanita yang dimilikinya, sebab hal itu akan lebih memungkinkan tidak akan berbuat penyelewengan. ${ }^{9}$

Sedangkan dari hadis-hadis Nabi, di antaranya diriwayatkan oleh Tirmidzi: "Bahwa Ghailan ibn Salamah ketika masuk Islam mempunyai 10 orang istri, maka Nabi pun berkata kepadanya: "pilihlah empat (sebagai istrimu), dan ceraikan yang lainnya". ${ }^{10}$

Hadis di atas menjelaskan bahwa poligami hingga batas empat dibolehkan oleh Nabi. Begitu

\footnotetext{
${ }^{7}$ Muhammad Ali al-Shabuni, Rawâi' al-Bayân Tafsir Ayat al-Ahkâm, (Beirut: Dâr al-Fikr, t.th), Juz II, h. 420.

8 Al-Jasshas, Ahkam al-Qur'an, (Beirut: Dar al-Kitab alIslamiyah, t.th.), h. 54

${ }^{9}$ Ibnu Jarir al-Thabari, Jami' al-Bayan fi Tafsir al-Qur'an, (Beirut: Dar al-Fikr, 1958), Jilid VI, h. 155-157

${ }^{10}$ Al-Tirmidzi, Sunan al-Tirmidzi, (Beirut: Dar al-Kutub alIlmiyyah, t.t), h. 1047
}

juga dalam sahih muslim disebutkan, Aisyah memahami surat al-Nisa' ayat 3 itu bahwa jika para pemelihara perempuan yatim khawatir dengan mengawini mereka tidak mampu berlaku adil, sebaiknya mengawini perempuan lain. Oleh sebab itu, ayat yang membolehkan poligami sebenarnya bukanlah menunjuk pada sifat dan makna yang berlaku umum, tapi mengandung suatu maksud, yaitu menegakkan keadilan terhadap anak yatim.

Analisa yang mungkin bisa dijadikan sandaran bagi adanya alasan-alasan keadaan istri yang bisa menyebabkan suami diizinkan poligami kiranya dapat dilacak dari konteks ayat, sejarah poligami orang-orang Arab pra Islam, dan memahami latar belakang poligami Nabi.

Sebelum ayat 1-4 surat al-Nisa' turun, perlakuan wali terhadap anak-anak yatim yang di bawah pengasuhannya umumnya tidak berlaku adil. Banyak wali yang ingin menikahi anak yatim untuk menguasai hartanya atau menikahkan anak yatim tersebut dengan anaknya agar terjadi percampuran harta yang dapat menambah kekayaannya. Bahkan ada wali yang menahan anak yatim untuk tidak menikah, atau menikah tapi dengan calon pilihan si wali agar si wali tersebut mendapat keuntungan dari pengurangan mahar, belanja, dan si walipun tetap secara tak langsung terus menguasai hakhak perdata si yatim. ${ }^{11}$

Menurut al-Khudari Bek, kedatangan Rasulullah saw membawa syari'at Islam berhadapan dengan tata aturan yang telah ada dan diikuti umat. Tata aturan itu oleh Alquran tidak seluruhnya dihapuskan, tidak pula seluruhnya ditolak, ada kalanya tetap diperlakukan yakni pada aturan yang tidak merusak (mudharat), dalam arti masih diterima Islam, dan ada kalanya tata aturan itu diganti dengan yang baru karena tidak cocok dengan maqâsid al-tasyrî̀. ${ }^{12}$

Pada waktu Alquran turun, praktek poligami sudah biasa dilaksanakan masyarakat Arab dengan jumlah tak terbatas. Orang-orang Yahudi dan Nashrani saat itu juga tidak mengharamkannya. Jadi tidak diperlukan perintah untuk melaksanakan

${ }^{11}$ Abdul Nashir Taufiq al-'Atthar, Poligami Ditinjau dari Segi Agama, Sosial, dan Perundang-Undangan, alih bahasa Chadijah Nasution, (Jakarta: Bulan Bintang, 1976), Cet. ke-1, h. 111.

${ }^{12}$ Muhammad al-Khudari Bek, Tarikh al-Tasyri' al-Islami, (Kairo: maktab al-Tijariah Kubra, 1965), h. 19. 
poligami itu. Yang diperlukan saat itu adalah perintah untuk membatasi poligami pada dua, tiga, atau empat sebagai batas yang maksimal. Pembatasan ini perlu agar orang jangan sampai wali terpaksa memakan harta anak yatim yang dipeliharanya, karena keperluannya untuk memberi nafkah kepada istri-istri dan anak-anaknya yang banyak. ${ }^{13}$

Redaksi yang dipakai dalam Alquran untuk menerangkan bolehnya sesuatu biasanya menggunakan kata-kata "Lâ Junaha 'Alaikum", "Uhilla lakum" dan gaya bahasa lain yang menunjukkan boleh. Tapi dalam kasus ini redaksi Alquran muncul dengan bentuk perintah "Fankihû" sebagai jawab syarat dari "Wa in Khiftum. .". Ini berarti Allah Swt menghendaki terlaksananya perintah yang lebih penting daripada sekedar bolehnya poligami, yaitu merealisasikan keadilan yang ditujukan bagi wali dalam pengurusan anak-anak yatim yang dibawah perwaliannya.

Dalam mengimplementasikan keadilan terhadap anak-anak yatim itu kadangkala wali menemui kesulitan seperti merasa segan masuk ke rumah anak-anak yatim dan ibu mereka dalam rangka melihat kondisi dan mengetahui apa-apa yang mereka butuhkan, karena bukan muhrimnya. Untuk menghindari fitnah, maka wali dalam hal ini dianjurkan untuk mengawini anak yatim tersebut atau ibunya. ${ }^{14}$

Selain itu, dalam konteks sejarah, ayat ini turun setelah selesainya perang Uhud yang memakan korban tewas 70 orang laki-laki dari 700 tentara Islam, akibatnya banyak muslimah yang janda dan anak yatim yang terlantar dan butuh pertolongan pemeliharaan. Menurut konteks sosial saat itu, jalan terbaik untuk memelihara dan menjaga para janda dan anak yatim adalah dengan menikahi mereka, dengan syarat harus adil. ${ }^{15}$ Jadi menikahi janda dan atau anak-anak yatim saat itu adalah sebagai wujud pertolongan, bukan memenuhi kebutuhan/kepuasan seks.

Indikasi motif di atas semakin kuat jika mengamati lebih lanjut perjalanan sejarah Nabi Muhammad saw yang sunnahnya menjadi panutan.

\footnotetext{
${ }^{13}$ Muhammad al-Khudari Bek, Tarikh al-Tasyri'..., h. 119

${ }^{14}$ Muhammad al-Khudari Bek, Tarikh al-Tasyri'..., h. 115.

${ }^{15}$ Asghar Ali Engineer, Hak-hak Perempuan Dalam Islam, terj. Farid Wajidi dan Cici Farkha Assegaf, (Yogyakarta: LSPPA \& CUSO, 1984), h. 143-144.
}

Beliau ternyata menikah sejak usia 25 tahun hingga berumur 54 (selama 29 tahun) hanya dengan seorang istri (monogami). Baru setelah berumur 54 tahun-bila dihitung tinggal sisa usia 9 tahun sampai wafatnya umur 63 tahun-beliau beristri lebih dari seorang atau melakukan poligami. Dan baru setelah dua tahun sepeninggal Khadijah Rasul berpoligami.

Dalam memahami latar belakang kebolehan poligami, Ali al-Shabuni misalnya, mencoba menyusun daftar motivasi poligami yang dilakukan Nabi dengan menjelaskan hikmah-hikmah poligami yang ditemukan saat itu. Al-Shabuni menangkap 4 hikmah penting yang menyertai poligami Nabi yaitu hikmah ta'limiyah, hikmah tasyri'iyah, hikmah ijtima'iyah, dan hikmah siyasiyah. ${ }^{16}$

Pertama, hikmah ta'lîmiyah dimaksudkan bahwa Nabi melakukan poligami untuk kader-kader wanita sebagai guru agama buat kaum wanita lainnya. Ini karena banyak wanita yang segan dan malu bertanya langsung kepada Nabi mengenai masalah agama, khususnya yang berkaitan dengan masalah kewanitaan seperti tentang haid, nifas, janabah, dan urusan-urusan suami istri. Kalaupun ada wanita yang bertanya, beliau kadangkala terpaksa harus menerangkannya dengan bahasa kinayah yang kemungkinan besar tidak dipahami dengan benar oleh wanita tersebut. Kedua, hikmah tasyrî'iyah yang dimaksudkan untuk membatalkan sebagian adat istiadat jahiliah yang menyimpang saat itu. Sebagai contoh Nabi mengawini Zainab mantan istri Zaid ibn Haritsah (anak angkat Nabi) untuk menjelaskan kepada masyarakat bahwa hal itu tidak terlarang, sebab pada saat itu berkembang anggapan bahwa status anak angkat sama seperti anak kandung dalam hal waris, thalaq, perkawinan, hurmat al-mushaharah, dan muharramat al-nikah. Bahkan Zaid saat itu sering juga dipanggil dengan nama Zaid ibn Muhammad. Ketiga, hikmah ijtimâ'iyah yang dimaksudkan untuk lebih mempererat ikatan persaudaraan Nabi dengan suku-suku Arab Quraisy dengan menikahi anak tokoh dari suku tersebut. Sebagai contoh perkawinan Nabi dengan Aisyah binti Abu Bakar yang merupakan wanita pujaan kaumnya, dan Hafshah binti Umar yang menjadi buah hati sibiran tulang ayahnya ${ }^{17}$, yang terkenal dengan

\footnotetext{
${ }^{16}$ Muhammad Ali al-Shabuni, Rawâi' al-Bayân. ., Juz II, h. 318.

${ }^{17}$ Hafshah binti Umar ibn al-Khattab sebenarnya adalah
} 
kejujuran dan keikhlasannya. Keempat, hikmah siyâsiyah yang dimaksudkan untuk menarik simpati, mengokohkan ikatan keluarga dan persaudaraan. Sebagai contoh kasus Nabi mengawini Juwairiyah binti al-Harits, bangsawati bani al-Musthaliq yang tertangkap sebagai salah satu tawanan perang. Nabi menawarkan Juwairiyah untuk menikah dengan beliau atau membayar tebusan untuk pelepasan dirinya. Juwairiyah ternyata memilih tawaran menikah dengan Nabi, maka Nabipun lalu tidak hanya menikahi Juwairiyah tapi juga membebaskan seluruh tawanan perang lainnya. Mengetahui pernikahan Juwairiyah dengan Nabi, kaum bani al-Musthaliqpun merasa terangkat derajat dan martabatnya sehingga akhirnya keluarga Juwairiyah dan seluruh suku bani al-Musthaliq masuk Islam dengan sukarela. ${ }^{18}$

Dari beberapa penjelasan di atas, secara global dapatlah ditegaskan bahwa motivasi dan alasan poligami itu adalah untuk pertolongan, peningkatan pendidikan, mempererat hubungan kekerabatan, dan menarik simpati musuh yang intinya demi memperlancar misi dakwah Islam.

Selanjutnya Sayyid Sabiq juga mengemukakan hikmah poligami yang cukup banyak yang ringkasannya adalah sebagai berikut: ${ }^{19}$

1. Memperbesar jumlah umat karena keagungan itu hanyalah bagi yang berjumlah banyak

2. Mengurangi jumlah janda sambil menyantuni mereka

3. Mengantisipasi kenyataan bahwa jumlah wanita berlebih/lebih banyak dibandingkan pria

4. Mengisi tenggang waktu yang lowong karena secara kodrati pria itu lebih panjang masa membutuhkan berhubungan seks, baik karena usia lanjut yang lebih cepat pada wanita dalam hal seks (menopause), ataupun karena tenggang waktu sebab haid dan nifas

\footnotetext{
wanita yang tidak lagi muda dan tidak juga cantik. Ketika suami Hafshah meninggal dalam suatu peperangan, Umar merasa gelisah melihat nasib putri kesayangannya, lalu Umar menawarkan putrinya kepada Abu Bakar untuk dikawini, namun Abu Bakar menolak, begitu juga ketika ditawarkan kepada Usman ibn Affan. Kemudian Umar melaporkan peristiwa penolakan sahabatnya tersebut, maka Nabipun mengatakan:"Ia (Hafshah) akan mendapatkan suami yang lebih baik dari Abu Bakar dan Usman, karena saya akan menikahinya".

${ }^{18}$ Muhammad Ali al-Shabuni, Rawâi' al-Bayân..., h. 319-325.

${ }^{19}$ Sayyid Sabiq, Fiqh al-Sunnah, (Beirut: Dâr al-Fikr, t.th.), Juz VI, h. 264-275
}

5. Dapat mengatasi kalau istri (pertama) mandul

6. Di tempat yang menganut pemaksaan monogami terjadi banyak kefasikan, banyaknya pelacur, dan banyak pula anak yang lahir di luar nikah.

Dari uraian Sayyid Sabiq tersebut, ternyata ketimpangan jumlah wanita yang lebih banyak dibanding pria, kebutuhan seksual pria yang tak terpenuhi, dan kemandulan wanita juga bisa dijadikan alasan poligami. Padahal dalam Fikih lima mazhab misalnya, secara eksplisit tidak ada disebutkan khusus alasan-alasan poligami seperti yang diuraikan Ali al-Shabuni maupun Sayyid Sabiq. Sebagai contoh alasan untuk mengakomodir kebutuhan seksual pria yang tak terpenuhi oleh istri, justru dibahas dalam kajian fasakh ${ }^{20}$ pada perkawinan karena cacat, tanpa menyinggung masalah poligami. Mengenai cacat yang dapat menyebabkan fasakh misalnya terdapat beberapa hadis Nabi, di antaranya:

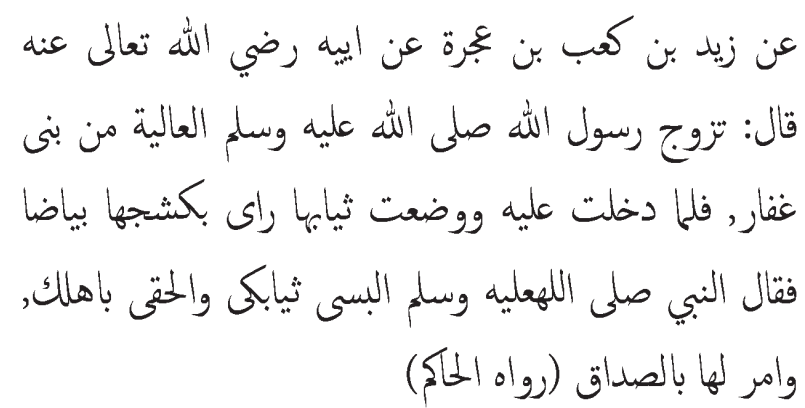

"Dari Zaid ibn Ka'ab ibn Ujrah dari ayahnya r.a. beliau berkata: Rasulullah saw mengawini Aliyah , wanita dari Bani Ghifar. Setelah dia masuk pada (kamar) beliau dan meletakkan pakaiannya, beliau melihat belang putih pada sekitar bagian pinggulnya. Lalu nabi saw bersabda kepadanya: pakailah pakaianmu dan pulanglah engkau ke keluargamu, danbeliau suruh berikan mas kawinnya" (Diriwayatkan oleh al-Hakim. Dalam sanadnya terdapat Jamil ibn Yazid, dia itu perawi yang tidak dikenal, dan banyak diperselisihkan tentang gurunya). ${ }^{21}$

Pada hadis lain dengan redaksi yang agak

${ }^{20}$ Alasan fasakh yang berdalil pada hadis Nabi:"Alhiqî Biahliki. ."bisa juga dipahami sebagai thalaq, yang berarti dapat pula dijadikan alasan thalaq. Ini karena kata yang dipakai Nabi itu merupakan sebagian dari sindiran thalaq. Lihat Mahmud Syaltut dan M. Ali al-Sayis, Perbandingan Mazhab Dalam Masalah Fiqh, Alih bahasa: Ismuha, (Jakarta: Bulan Bintang: 1993), Cet. ke-7, h. 215

${ }^{21}$ Muammad ibn Ismail al-Kahlani al-Shan'ani, Subul alSalâm, (Semarang: Toha Putra, t.th), Juz III, h. 135 
berbeda tapi inti matannya sama disebutkan:

$$
\begin{aligned}
& \text { انه صلى الله عليه وسلم تزوج امراة من بنى غفار, فلما } \\
& \text { دخلث عليه راى بكثجها وضها فردها اللى اهلها وقلا: } \\
& \text { دلستم علي (رواه ابو داود) }
\end{aligned}
$$

"Sesungguhnya Rasulullah saw mengawini seorang wanita dari Bani Ghifar. Setelah dia masuk (kamar) beliau, maka beliau melihat pada bagian sekitar pinggulnya belang putih. Lalu beliau mengembalikan wanita itu kepada keluarganya seraya bersabda: Kalian telah menipu saya." (HR. Abu Daud)

Mayoritas ulama berpendapat bahwa cacat tetap bisa menjadi alasan fasakh sekalipun mereka berbeda pendapat tentang perinciannya. Diriwayatkan dari Ali r.a. dan Umar r.a. ia berkata sesungguhnya: tidak boleh dikembalikan kaum wanita (yang sudah dinikahi itu) kecuali karena sempat cacat, yaitu gila, penyakit kulit/belang, penyakit kusta/lepra, dan karena penyakit pada alat kelaminnya. Akan tetapi sanadnya munqathi yaitu hadis yang putus satu atau dua sanadnya selain pada sahabat dan tabi'in. Al-Baihaqi meriwayatkan dengan sanad yang bagus dari Ibnu Ibnu Abbas r.a: Ada empat macam cacat wanita yang tidak boleh dalam jual beli dan pernikahan, yaitu gila, wanita yang kulit belang, yang berpenyakit kusta (lepra), dan wanita yang rusak alat kelaminnya. ${ }^{22}$

Mengenai cacat yang diderita wanita, para ulama mazhab berbeda pendapat mengenai kapan mulai terjadi cacat, beberapa rincian cacat, hak fasakh dan implikasi hukumnya sebagai berikut: ${ }^{23}$

Pertama, mengenai cacat berupa penyakit gila. Maliki, Syafi'i, dan Hambali sepakat bahwa suami boleh memfasakh akad karena penyakit gila yang diderita istrinya. Syafi'i dan Hambali mengatakan, karena penyakit gila, faskh ditetapkan bagi keduanya, baik penyakit gila tersebut terjadi sebelum akad atau sesudahnya, sesudah percampuran atau belum tanpa harus menunggu beberapa waktu seperti pada impotensi. Maliki berpendapat bahwa apabila gila itu terjadi sebelum akad, kedua belah pihak

${ }^{22}$ Muammad ibn Ismail al-Kahlani al-Shan'ani, Subul alSalâm..., h. 137.

${ }^{23}$ Muhammad Jawad Mughniyah, Al-Fiqh 'Ala al-Madzâhib al-Khamsah, (Beirut: Dâr al-Fikr, t. th.), h. 66-68. boleh melakukan fasakh dengan syarat ada ancman bahaya bagi yang waras bila bergaul denganyang gila itu. Tetapi bila gila itu terjadi setelah akad, maka yangberhak atas fasakh hanyalah istri, sesudah diberi tenggang waktu satu tahun karena ada kemungkinan sembuh dalam masa tersebut, sedangkan suami tidak berhak atas fasakh karena istrinya menderita gila yang terjadi setelah akad. Adapun Imamiyah berpendapat bahwa suami tidak boleh memfasakh perkawinan karena istrinya terkena gila yang terjadi setelah akad, karena masih terbuka kemungkinan baginya menjatuhkan thalak. Tetapi istri boleh melakukan fasakh karena suaminya gila baik terjadi sebelum atau sesudah akad, atau setelah persetubuhan.

Kedua, penyakit sopak dan kusta. Maliki, Syafi'i, dan Hambali berpendapat bahwa kedua penyakit tersebut merupakan cacat bagi kedua belah pihak, pria maupun wanita. Kedua pihak boleh melakukan fasakh jika ditemukan penyakit tersebut pada pasangannya. Orang yang menderita kedua penyakit tersebut bagi Syafi'i dan Hambali hukumnya sama dengan orang gila. Sedang Maliki mengatakan bahwa wanita boleh memfasakh jika penyakit tersebut ditemukan ditemukan sebelum dan sesudah akad nikah. Bagi pria boleh melakukan fasakh jika penyakit kusta dalam diri wanita tersebut ditemukan sebelum atau ketika akad. Berbeda dengan penyakit sopak, jika ditemukan sebelum akad, maka kedua belah pihak mempunyai hak yang sama untuk fasakh. Tetapi kalau sopak tersebut terjadi sesudah akad, maka hak tersebut hanya bagi wanita dan tidak bagi pria. Penyakit sopak ringan yang ditemukan sesudah akad, tidak berpengaruh terhadap kelangsungan akad. Terhadap orang yang menderita sopak atau kusta, hakim harus memberi masa tenggang setahun penuh bila ada kemungkinan sembuh dalam jangka waktu itu. Adapun Imamiyah berpendapat bahwa sopak dan kusta adalah dua penyakit yang menyebabkan seorang pria boleh melakukan fasakh, tetapi tidak boleh bagi wanita, dengan syarat hal itu terjadi sebelum akad nikah dan pria tersebut tidak mengetahuinya. Sedangkan bagi istri, ia tidak mempunyai hak untuk fasakh jika salah satu penyakit tersebut terjadi pada pria.

Ketiga, penyakit al-Ritq, al-Qarn, al-'Afal, dan al-Ifdha'. Al-Ritq adalah tersumbatnya lubang vagina yang menyebabkan terjadinya kesulitan bersenggama. Al-Qarn adalah benjolan yang 
tumbuh pada kelamin wanita yang mirip tanduk domba, al-'Afal adalah daging yang tumbuh pada kemaluan wanita yang selalu mengeluarkan cairan, dan al-Ifdha adalah menyatunya kedua saluran pembuangan. Menurut Maliki dan Hambali, adanya salah satu di antara keempat jenis cacat tadi menyebabkan seorang suami berhak membatalkan perkawinan. Syafi'i berpendapat bahwa yang menyebabkan terjadinya faskh adalah al-Ritq dan al-Qarn saja, sedang al-'Afal dan al-Ifdha tidak berpengaruh terhadap akad. Adapun menurut Imamiyah, al-Qarn dan al-Ifdha mempunyai pengaruh dalam pembatalan perkawinan, sedangkan al-Ritq dan al-'Afal tidak mempunyai pengaruh sama sekali.

\section{Alasan-Alasan Poligami Di Dunia Islam 1. Indonesia}

Negara Republik Indonesia yang mayoritas penduduknya beragama Islam bermazhab Syafi' $i$, dalam sejarahnya telah berlaku tiga sistem hukum, yaitu sistem hukum Islam, sistem hukum adat, dan sistem hukum Barat, baik yang berasal dari Eropa kontinental yang disebut civil law maupun yang berasal dari Eropa kepulauan yang dikenal dengan common law atau hukum anglo saxon.

Indonesia memiliki sistem hukum keluarga yang unik, karena campuran antara hukum Islam dan hukum adat. Di bawah pemerintahan Hindia Belanda dan jepang, hukum keluarga yang diberlakukan di Indonesia adalah hukum adat yang dimodifikasi dengan hukum Islam. Hal ini telah diatur sejak tahun 1882 dengan peraturan tentang peradilan agama. ${ }^{24}$

Pada tahun 1929, diberlakukan Ordonansi perkawinan Muslim yang hanya berlaku untuk Jawa dan Madura. Tahun 1946, Indonesia membentuk peraturan tentang pencatatan perkawinan dan perceraian. Sejak tahun 1950-an Indonesia telah berusaha untuk membentuk draft hukum perkawinan yang komprehensif dan dapat diberlakukan bagi seluruh warga negara. Namun usaha ini tertunda karena banyaknya hambatan baik dari non muslim maupun kalangan Islam tradisional. Namun akhirnya berkat perjuangan yang tak mengenal lelah, UU No. 1 tahun 1974 tentang perkawinan dapat disahkan dan

24 Tahir Mahmood, Personal Law in Islamic Countries, (New Delhi: Academy of Law and religion, 1987), h. 205 diberlakukan dengan PP No. 9 tahun 1975 sebagai pelaksanaannya. ${ }^{25}$

Lahirnya Undang-Undang Perkawinan Nomor 1 tahun 1974 merupakan kelanjutan dari penjabaran UU No.1 tahun 1970 tentang PokokPokok Kekuasaan Kehakiman, khususnya untuk melengkapi hukum materil Peradilan Agama. Oleh karena itu pula, Undang-Undang Perkawinan ini dapatlah dikatakan sebagai langkah awal dari usaha legislasi hukum Islam di Indonesia untuk kemudian dilanjutkan dengan Undang-Undang Peradilan Agama No. 7 tahun 1989 dan Inpres No. 1 tahun 1991 tentang Kompilasi Hukum Islam.

Berdasarkan UU No 1 tahun 1974, maka prinsip perkawinan di Indonesia adalah monogami. Namun masih dimungkinkan seorang pria melangsungkan poligami maksimal empat dengan persetujuan pengadilan (pasal 3 ayat 2)

Izin beristri lebih dari seorang, termasuk PNS, hanya dapat diberikan apabila memenuhi sekurang-kurangnya salah satu syarat alternatif, dan ketiga syarat kumulatif. ${ }^{26}$ Adapun syarat-syarat alternatif ialah:

a)Isteri tidak dapat menjalankan kewajibannya sebagai istri; b) istri mendapat cacat badan atau penyakit yang tidak dapat disembuhkan; atau c) istri tidak dapat melahirkan keturunan. ${ }^{27}$

Sedang syarat kumulatif adalah:

a) ada persetujuan tertulis dari istri-istri; b) adanya kepastian bahwa suami mampu menjamin keperluan hidup istri dan anakanak mereka; c) ada jaminan tertulis bahwa suami akan berlaku adil terhadap istri-istri dan anak-anaknya. ${ }^{28}$ Persetujuan istripun harus dipertegas di pengadilan.

\footnotetext{
${ }^{25}$ Tahir Mahmood, Personal Law. ., h. 207-208.

${ }^{26}$ PP No. 10 Thn 1983 pasal 10 ayat 1: "Izin untuk beristri lebih dari seorang hanya dapat diberikan oleh pejabat apabila memnuhi sekurang-kurangnya salah satu syarat alternatif, dan ketiga syarat kumulatif sebagaimana dimaksud dalam ayat 2 dan ayat 3 pasal ini.

${ }^{27}$ UU No. 1/1974 pasal 4 ayat 2; PP No. 9/1975 pasal 41 huruf a; PP No. 10/1983 pasal 10 ayat 2, dan KHI pasal 57

${ }^{28}$ UU No. 1/1974 pasal 5; PP No. 9/1975 pasal 41 huruf b dan c; PP No. 10/1983 pasal 10 ayat 3, dan KHI pasal 58 ayat 1, "Untuk dapat mengajukan permohonan kepada Pengadilan sebagaimana dimaksud dalam pasal 4 ayat 1 UU ini, harus dipenuhi syarat-syarat sebagai berikut: a) adanya persetujuan dari istri/istri-istri; b) adanya kepastian bahwa bahwa suami mampu menjamin keperluan-keperluan hidup istri-istri dan anak-anak mereka; c) adanya jaminan tertulis bahwa suami akan berlaku adil terhadap istri-istri dan anak-anak mereka". Tapi pada KHI tidak ditulis poin c
} 


\section{Malaysia}

Mayoritas penduduk negara Malaysia (55\%) adalah muslim bermazhab Syafi'i. Negara ini terletak di Asia Tenggara dengan memakai bahasa Melayu dan Inggris sebagai bahasa resmi negara. Pada masa pemerintahan Inggris di akhir abad ke-19, semenanjung Malaka terdiri atas kerajaankerajaan kecil dan budaya Islam diberlakukan di seluruh negeri tersebut, seperti hukum perkawinan, hukum perceraian, dan hukum waris. ${ }^{29}$

Sebelum datangnya penjajah, hukum yang berlaku di Malaysia adalah hukum Islam bercampur hukum adat. ${ }^{30}$ Setelah Malaysia memperoleh kemerdekaannya, konstitusi federal Malaysia tahun 1957 begitu juga konstitusi federal tahun 1963 mendeklarasikan agama Islam sebagai agama resmi negara. ${ }^{31}$ Hukum Islam dan administrasinya diberlakukan secara resmi di seluruh wilayah negara Malaysia meliputi Perak, Selangor, Negeri Sembilan, Pahang, Klantan, Trengganu, Kedah, dan Johor. Pada dua negara bagian yaitu Sabah dan Serawak, penduduk muslim merupakan minoritas. Sabah yang memiliki jumlah penduduk muslim lebih sedikit dari Serawak, memakai administrasi hukum Islam pada tahun 1971. Sedang Serawak masih menerapkan Undang-Undang Mahkamah Melayu tahun 1915. Hukum negara-negara bagian di Malaysia memuat ketetapan hukum keluarga melalui pengadilan-pengadilan kathis. ${ }^{32}$

Perundang-undangan Malaysia telah mengalami dua kali pembaharuan. Pertama tahun 1976-1980 yang berisi tentang perkawinan dan perceraian. Lalu pembaharuan yang kedua dilaksanakan tahun 1983-1985 yang diberi nama Islamic Family Law Act. Hukum baru ini dilaksanakan tahun 1983 di Kelantan, Negeri Sembilan, dan Malaka. Kemudian tahun 1984 dilaksanakan di Kedah, Selangor, dan wilayah Persekutuan, serta tahun 1985 dilaksanakan di Penang. ${ }^{33}$

${ }^{29}$ Tahir Mahmood, Family Law Reform in the Muslim World, (Delhi: N.M Tripathi Pvt, 1972), Cet. ke-1, h. 219.

${ }^{30}$ Ismail bin Mat, 'Adat and Islam in Malaysia: Study in Legal Conflict and Resulotion", (Philadelpia: Disertasi di Temple University, 1985), h. 30 sebagaimana dikutip Khoiruddin Nasution, Status Wanita di Asia Tenggara: Studi Terhadap Perundangundangan Perkawinan Muslim Kontemporer di Indonesia dan Malaysia, (Leiden-Jakarta: INIS, 2002), Cet. ke-1, h. 62

${ }^{31}$ Khoiruddin Nasution, Status Wanita. ., h. 63

${ }^{32}$ Lihat Tahir Mahmood, Family Law Reform in the Muslim World, (Delhi: N.M Tripathi Pvt, 1972), Cet. ke-1, h. 198-205

33 Tahir Mahmood, Personal Law in Islamic Countries, (New Delhi: Academy of Law and religion, 1987), h. 16
Berdasarkan UU Perkawinan Malaysia tentang boleh atau tidaknya seorang laki-laki melakukan poligami, ada tiga hal penting yang perlu diperhatikan, yakni syarat-syarat, alasanalasan boleh tidaknya poligami dan prosedurnya. Namun yang membedakannya dengan perundangundangan Indonesia ialah Malaysia tidak ada menegaskan tentang prinsip perkawinan, apakah monogami atau poligami. Dari tiga hal penting di atas, penulis akan membatasi masalah pada alasan-alasan yang digunakan oleh pihak suami terhadap keadaan pihak istri bagi kebolehan atau tidaknya poligami.

Dasar pertimbangan pengadilan untuk memberi izin atau tidak, dilihat dari pihak istri dan suami. Adapun alasan-alasan dari pihak istri adalah:

(1) kemandulan, (2) karena keuzuran jasmani, (3) karena tidak layak dari segi jasmani untuk bersetubuh, (4) sengaja tidak mau memulihkan hak-hak persetubuhan, atau (5) istri gila. ${ }^{34}$.

Sedang pertimbangan dari pihak suami adalah:

(1) mampu secara ekonomi untuk menanggung istri-istri dan anak keturunan, (2) berusaha untuk adil di antara para istri, (3) perkawinan itu tidak menyebabkan bahaya terhadap agama, nyawa, badan, akal pikiran atau harta benda istri yang telah lebih dahulu dinikahi, (4) perkawinan itu tidak akan menyebabkan turunnya martabat istri-istri atau orang-orang yang terkait dengan perkawinan, langsung atau tidak. ${ }^{35}$

\section{Iran}

Iran adalah sebuah negara Republik Islam yang jumlah penduduknya mencapai 43.000 .000 dengan $98 \%$ beragama Islam. Di antara warga muslim Iran, sekitar $8 \%$ Sunni, sedang sisanya $92 \%$ adalah pengikut Syi'ah dua belas imam (dari paham

${ }^{34}$ UU Negeri Sembilan, UU Pinang, UU Pahang, UU Wilayah Persekutuan, dan UU Selangor pasal 23 ayat 4 a menyatakan: "Bahawa perkahwinan yang dicadangkan itu adalah patut dan perlu, memandangkan kepada, antar lain, hal-hal keadaan yang berikut, iaitu, kemandulan, keuzuran jasmani, tidak layak dari segi jasmani untuk persetubuh, sengaja ingkar mematuhi perintah untuk pemulihan hak-hak persetubuhan, atau gila di pihak isteri atau isteri-isteri yang sedia ada". Khoiruddin Nasution, Status Wanita di Asia Tenggara: Studi Terhadap Perundangundangan Perkawinan Muslim Kotemporer di Indonesia dan Malaysia, (Leiden-Jakarta: INIS, 2002), Cet. Ke-1, h. 112.

${ }^{35}$ Khoiruddin Nasution, Status Wanita. ., h. 112. 
ushuliyah, dan terdapat sedikit paham akhbariyah di Khuzistan). Penganut Kristen Armanean dan Kristen Chaldean diperkirakan sekitar $1 \%$, dan terdapat juga sejumlah kecil penganut Yahudi. Selain itu, terdapat 30.000 penganut Zoroastria, 50.000 Bahais, beberapa kelompok kecil penganut Ali Ilahis, Babis, Syaikhis, dan Ismailiyyah. Warga Iran mayoritas adalah etnis Persia (63 \%), namun 26 \% warganya berbahasa dengan bahasa Turki (yakni Azeis, Baluchis, Qadyqai, Turkoman) dan lainnya. Terdapat sekitar 2 juta suku Kurdi yang tinggal di Iran, ada juga minoritas keturunan Arab yang tinggal di Khuzistan (yang oleh orang Irak mereka disebut "Arabistan"). ${ }^{36}$

Sejak lama Iran telah dikenal sebagai pusat Islam Syia'h. Mereka bermazhab fikih Ja'fari atau Itsna Asyariah yang menerapkan hukumnya di Pengadilan Agama.Undang-undang (Civil Code) Iran yang lengkap telah diberlakukan sejak 19281935, sebagai refleksi kombinasi hukum Islam dan hukum sipil Prancis. ${ }^{37}$

Iran dengan Family Protection Act of 1967, yang diperbaharui tahun 1975 membuat cara sendiri untuk menjamin hak-hak wanita dalam praktek poligami (membatasi kemungkinan poligami), yakni sebagai tambahan terhadap ketetapan bahwa suami yang akan berpoligami harus mendapat izin dari pengadilan, yang ditentukan oleh terpenuhi atau tidaknya syarat: (1) kemampuan ekonomi dan (2) berbuat adil di antara para istrinya. ${ }^{38} \mathrm{Di}$ samping itu harus ada izin/persetujuan dari istrinya atau karena ada sesuatu yang menjadi alasan. Pada pasal 16 disebutkan: "Seorang suami tidak berhak menikah lagi dengan wanita lain (poligami) kecuali ada izin/persetujuan dari istri pertama, atau karena alasan-alasan:

(1)istri pertama tidak mampu berkumpul (bergaul) dengan suami, (2) ada penyakit yang tidak dapat disembuhkan, (3) istri dipenjara minimal lima tahun, (4) kecanduan minumminuman keras, judi, dan semacamnya, (5) meninggalkan keluarga, (6) hilang. ${ }^{39}$

\footnotetext{
${ }^{36}$ Cyrill Glasse, Ensiklopedi Islam, (Jakarta: RajaGrafindo Persada, 1996), Cet. ke-1, h. 170.

${ }^{37}$ Tahir Mahmood, Family Law Reform..., h. 214

${ }^{38}$ Norman Anderson, Law Reform in the Muslim World, (London: The Athlone press, 1976), h. 113. Lihat juga Khoiruddin Nasution, Status Wanita. ., h. 113.

${ }^{39}$ Khoiruddin Nasution, Status Wanita. ., h. 113.
}

\section{Somalia}

Republik Demokrasi Somalia terletak di Afrika sebelah Timur, pesisir sebelah utaranya menghadap ke Teluk Aden dan pesisir sebelah timurnya menghadap ke samudera Hindia. Dengan ibukota Mogadishu, Somalia berbatasan darat dengan Kenya, Ethiopia, dan Djibouti di sebelah Barat. Menurut Esposito, kaum muslim Somalia meliputi hampir 99\% dari penduduknya yang diperkirakan berjumlah delapan hingga sepuluh juta jiwa. ${ }^{40}$ Mereka kebanyakan pengikut mazhab Syafi'i dalam berhukum. Walaupun begitu, adat Somalia masih tetap dipegang kuat terutama dalam hal kewarisan.

Sejarah modern Somalia bertitik tolak dari kolonialisasi Inggris dan Italia sejak pertengahan tahun 1880-an. Melalui penjajahan inilah Somalia mengadaptasi berbagai hukum Barat (Inggris) seperti hukum waris tahun 1865, Majority Act 1875 dan hukum acara perdata 1908. Setelah merdeka pada bulan Juli 1960, Somalia mulai membentuk hukum dan undang-undang negaranya sendiri. Tetapi selama dekade pertama hal ini berjalan terlalu lambat dan dikuasai oleh status quo. Perubahan penting berlangsung setelah kudeta (cup de etat) militer Jenderal Mohammad Siyad Barre tahun 1969 yang memperkenalkan sosialisme sebagai ideologi resmi. ${ }^{41}$

Di bawah rezim militer sosialis inilah dilakukan berbagai pembaharuan hukum yang banyak bertentangan dengan ketentuan Islam sehingga banyak menimbulkan perlawanan. Pada 11 Januari 1975 diberlakukanlah UU keluarga Somalia dengan tujuan untuk menghilangkan hukum adat yang dianggap menganggu kebijakan negara. Meskipun UU Keluarga Somalia ini menyatakan didasarkan pada mazhab Syafi'i serta prinsip-prinsip umum dan keadilan sosial, tetapi proses pembentukannya harus diakui membawa begitu banyak korban umat Islam. Presiden Barre misalnya, telah mengeksekusi 10 pimpinan agama karena memprotes secara damai UU tersebut. ${ }^{42}$

Undang-undang keluarga Somalia menetap-

\footnotetext{
${ }^{40}$ John L. Esposito, The Oxford Encyclopaedia of Modern Islamic World, (New York-Oxford: Oxford University Press, 1991), Jilid IV, h. 91-92.

${ }^{41}$ Tahir Mahmood, Family Law Reform..., h. 254.

${ }^{42}$ Mengenai penentangan ini, bisa dilihat pada The Encyclopaedia of Islam New Edition, (Leiden: E.J. Brill, 1997), Jilid IX, h. 723.
} 
kan bahwa poligami hanya dapat dilakukan dengan izin pengadilan, karena ada alasan hukum, yakni:

(1) istrinya mandul dengan bukti surat dokter,

(2) istri dipenjara lebih dari dua tahun, (3) istri meninggalkan rumah tanpa izin lebih satu tahun, atau (4) ada kebutuhan sosial. ${ }^{43}$

\section{Tunisia}

Di antara negara-negara yang berada di wilayah Maghrib_daerah paling Barat dari dunia Arab-yaitu Maroko dan Aljazair, maka Tunisia merupakan negara yang paling kecil. Pemerintahan Tunisia berbentuk Republik, dipimpin oleh seorang Presiden yang beribukota di Tunis. Islam menjadi agama resmi negara. Masyarakatnya mayoritas beragama Islam penganut mazhab Maliki dan sebagian Hanafi, karena itu dalam persoalan perdata, kedua mazhab tersebut sama-sama dipergunakan. Namun banyak di antara berbagai dinasti yang yang pernah berkuasa di Tunisia baik asing maupun asli Tunisia memiliki keyakinan yang berbeda-beda, seperti dinasti Syi'ah Fathimiyah sekitar abad X. Setelah dinasti ini tumbang, praktis kaum Syi'ah menjadi minoritas. Demikian juga halnya dengan mazhab Hanafi yang membentuk minoritas kecil di Tunisia, namun memberi pengaruh penting di negeri ini sampai protektorat Prancis datang pada tahun $1883 .{ }^{44}$

Pasca kemerdekaannya pada 20 Maret 1956, Tunisia segera menyusun berbagai pembaharuan dan kodifikasi hukum Islam berdasarkan mazhab Maliki dan Hanafi. Upaya pembaharuan ini didasarkan pada penafsiran liberal terhadap Syari'ah, terutama yang berkaitan dengan hukum keluarga. Lahirlah Majallat al-Ahwal al-Syakhsiyyah yang kontroversial. Menurut Esposito, di bawah kepemimpinan Presiden Habib Bourguiba inilah Tunisia menjadi negara Arab pertama

${ }^{43}$ Pada UU Somalia tahun 1975 pasal 13 menyebutkan: “ Tidak seorangpun boleh menikah lagi (poligami) kecuali setelah mendapat izin secara resmi dari pengadilan. Pengadilan memberi izin karena alasan-alasan: (i) istrinya mandul yang dibuktikan dengan keterangan dokter, dan kondisi ini tidak disadari sejak nikah (ii) istri dipenjara lebih dua tahun, (iii) istri meninggalkan rumah tanpa izin lebih satu tahun, atau (iv) ada kebutuhan sosial, yang ditentukan oleh Menteri Kehakiman dan Agama”. Tahir Mahmood, Personal Law. ., h. 257.

44 John L. Esposito, The Oxford Encyclopaedia of the Modern Islamic World, (New York-Oxford: Oxford University Press, 1991), Jilid. IV, h. 234. yang melarang poligami. ${ }^{45}$ Majallah itu sendiri mencakup materi hukum perkawinan, perceraian, dan pemeliharaan anak yang berbeda dengan ketetapan hukum Islam klasik. Pada perkembangan selanjutnya, Majallah atau Undang-Undang Status Personal tahun 1956 ini telah mengalami beberapa kali perubahan, penambahan dan modifikasi lebih jauh melalui amandemen Undang-Undang sampai dengan tahun 1981. Selanjutnya pemerintah Tunisia pada saat itu membentuk suatu komite di bawah pengawasan Syeikh al-Islam yaitu Muhammad Ju'ayad untuk memberlakukan undang-undang secara resmi. Syeikh Universitas Zaituna juga ikut berpartisipasi dalam komite tersebut. Dengan menggunakan sumber-sumber yang diperoleh, dari hasil-hasil komite Lai'hat, hukum keluarga ala Egypt, Yordania, Syiria, dan Turki Usmani. Komite tersebut mengajukan draft undang-undang hukum keluarga kepada pemerintah,dan akhirnya diberlakukanlah undang-undang tersebut pada tahun $1956 .{ }^{46}$

Undang-Undang tersebut memuat 167 pasal yang ditulis dalam 10 jilid yang dianggap cukup komprehensif, meskipun belum memuat undang-undang kewarisan. Undang-undang ini telah mengalami tujuh kali amandemen selama periode 1958-1966. Terakhir kali undang-undang ini diamandemen pada tahun 1981 (UU No. 7/1981), yang memperkenalkan beberapa modifikasi penting dari undang-undang sebelumnya.

Adapun alasan pembentukan dan pemberlakuan UU baru Tunisia tersebut adalah:

(i) untuk menghindari pertentangan antara pemikir mazhab Hanafi dan Maliki; (ii) untuk penyatuan pengadilan menjadi pengadilan nasional, sehingga tidak ada lagi perbedaan antara pengadilan agama dan pengadilan negeri; (iii) untuk membentuk UU modern, sebagai referensi para hakim; (iv) untuk menyatukan pandangan masyarakat secara keseluruhan yang diakibatkan adanya perbedaan dari mazhab klasik; (v) untuk memperkenalkan undang-undang baru yang sesuai dengan tuntutan modernitas. ${ }^{47}$ 239.

45 John L. Esposito, The Oxford Encyclopaedia. ., h. 235-

46 Tahir Mahmood, Personal Law in Islamic Countries, (New Delhi: Academy of Law and Religion, 1987), h. 152.

${ }^{47}$ JND. Anderson, "The Tunisian Law of Personal Status", dalam International and Comparative Law Quarterly, 7 April 
Undang-undang Tunisia yang terdiri dari 170 pasal tersebut berlaku untuk semua warga Tunisia, khususnya setelah dicapai kesepakatan dengan Prancis pada tanggal 1 Juli 1957. Dari berbagai pembaharuan yang terdapat dalam UU baru ini, ada dua hal yang (awalnya) mendapat respon negatif dari sejumlah kalangan, yakni larangan poligami dan keharusan perceraian di pengadilan. ${ }^{48}$

Mengenai praktek poligami, Tunisia melarangnya secara mutlak berdasarkan pada teks Undang-Undang pasal 18 yang dengan tegas meyatakan:

a. Poligami dilarang, siapa saja yang telah menikah sebelum perkawinan pertamanya benar-benar berakhir, lalu menikah lagi, akan dikenakan hukuman penjara selama satu tahun atau denda sebesar 240.000 malim atau dengan kedua-duanya.

b. Siapa yang telah menikah, melanggar aturan yang terdapat pada UU No. 3 Tahun 1957 yang berhubungan dengan aturan sipil dan kontrak pernikahan kedua, sementara ia masih terikat perkawinan dengan istri pertama, maka akan dikenakan hukuman yang sama

c. Siapa yang dengan sengaja menikahkan seseorang yang dikenai hukuman, menurut ketentuan yang tak resmi, ia bisa juga dikenakan hukuman yang sama. ${ }^{49}$

\section{Analisa Perbandingan}

Dari deskripsi tentang pengaturan alasan poligami yang dilakukan di negara Indonesia, Malaysia, Iran, Somalia, dan Tunisia, tampaknya ada perkembangan yang menarik untuk mendapat pembahasan dan kajian lebih lanjut.

Secara vertikal, keberanjakan hukum dalam perundang-undangan di lima negara tersebut terlihat dengan jelas melalui pengaturan alasanalasan poligami dan pelarangan poligami secara mutlak Alasan-alasan poligami karena keadaan istri sebenarnya tidak dijumpai secara eksplisit baik pada nash maupun pada pendapat ulama mazhab

1985, h. 262.

${ }^{48}$ Kiran Gupta, "Poligami Law Reform in Modern Status", dalam Islamic Law and Comparative Law, Vol. XIII, No. 2 Tahun 1992, h. 121

49 Tahir Mahmood, Personal Law in Islamic Countries History, Text and Comparative Analysis, (New Delhi: Academy of Law and religion, 1987), h. 155-157 sebelumnya. Kebanyakan ulama mazhab hanya membahas tentang keadilan dan kemampuan yang disyaratkan bagi suami yang akan melakukan poligami, dan lima mazhab sepakat atas hukum asal poligami yang mubah. Mereka tidak menyinggung sebegitu jauh alasan poligami karena keadaan istri atau melarangnya secara mutlak. Kalaupun ada, alasan-alasan itu bukanlah untuk poligami, tapi digunakan untuk fasakh dalam pernikahan. Sedangkan keempat negara di atas-selain Tunisia yang menolak poligami secara mutlakmenetapkan alasan-alasan rinci karena keadaan istri yang menyebabkan suami dapat berpoligami. Alasan poligami yang didasarkan pada konteks nash menurut ulama klasik selama ini dipahami adalah untuk pertolongan, yaitu menolong janda dan anak yatim. Sedang dalam Undang-Undang hukum keluarga keempat negara di atas, alasan pertolongan tersebut sangat implisit yang hanya dapat dipahami dan ditentukan oleh ketelitian hakim. Adapun Tunisia menetapkan larangan poligami yang sama sekali lepas dari kendali teks dan konteks nash serta mazhab Hanafi dan Maliki yang dianutnya.

Dengan demikian, negara Indonesia, Malaysia, Iran dan Somalia tampaknya dalam melakukan pembaharuan hukum keluarganya, khususnya masalah poligami cenderung memakai metode intra-doctrinal dan extra-doctrinal reform ${ }^{50}$ sekaligus, yakni dengan menggabungkan pendapat dari berbagai mazhab yang ada tentang kebolehan poligami, dan memberikan penafsiran terhadap alasan-alasan poligami yang bisa jadi diinspirasikan oleh alasan-alasan fasakh dalam pernikahan dengan mengambil ruh dan spirit dari substansi makna penetapan alasan-alasan fasakh dan tujuan perkawinan secara umum. Sedangkan Tunisia lebih cenderung memakai metode extra-doctrinal reform semata yang akhirnya menghasilkan kesimpulan larangan mutlak terhadap poligami.

Secara horizontal, di Indonesia yang umumnya bermazhab Syafi'i walau KHI-nya lintas mazhab,

\footnotetext{
${ }^{50}$ Intra-doctrinal reform ialah pembaharuan hukum keluarga Islam yang dilakukan dengan menggabungkan pendapat dari berbagai mazhab atau mengambil pendapat lain selain mazhab utama yang dianut, sedangkan extra-doctrinal reform ialah pembaharuan hukum keluarga Islam dengan cara memberikan penafsiran yang sama sekali baru terhadap nash yang ada. Idenya bisa diambilkan dari entitas pemikiran apa saja. Lihat M. Atho Mudzhar, Membaca Gelombang Ijtihad Antara Tradisi dan Liberasi, (Yogyakarta: Titian Ilahi Press, 1998) , h. 177
} 
membuat alasan poligami karena keadaaan istri dengan syarat alternatif yaitu istri tidak dapat berhubungan seksual, penyakit yang tak dapat disembuhkan, dan mandul.

Begitu juga Malaysia yang bermazhab Syafi'i ternyata menetapkan alasan yang lebih rinci lagi mengenai alasan poligami karena keadaan istri yang mandul, sudah uzur, tidak layak berhubungan seksual, dan gila.

Iran yang bermazhab Syi'ah dan terkenal dengan nikah mut'ahnya sebagai preventif bagi perzinaan, ternyata dalam masalah poligami juga menetapkan alasan-alasan yang cukup banyak yang terkesan memudahkan terjadinya poligami. Alasan-alasan karena istri tidak mampu berhubungan seksual, berpenyakit yang tak dapat disembuhkan, dipenjara, kecanduan miras, judi dan semacamnya, meninggalkan keluarga tanpa izin, dan hilang dapat dijadikan alasan bagi suami untuk berpoligami.

Sedangkan Somalia yang mayoritas penduduknya bermazhab Syafi'i plus hukum adat dalam masalah kewarisan, dalam masalah poligami turut serta menetapkan alasan-alasan poligami karena keadaan istri. Undang-undang Somalia menetapkan alasan hukum karena keadaan istri yang mandul, dipenjara lebih dari dua tahun, meninggalkan rumah tanpa izin lebih dari satu tahun, dan ada kebutuhan sosial.

Adapun Tunisia yang walaupun mayoritas penduduknya bermazhab Hanafi dan Maliki, namun karena pengaruh kultur dan institusi hukum Eropa, khususnya Perancis, serta pemahaman al-Nisa: 129 yang diartikan sebagai ketidakmampuan manusia berlaku adil terkecuali Nabi, maka dalam masalah poligami, hukum keluarganya melarang secara mutlak dan tidak memberi sedikitpun peluang pengecualian, bahkan bagi pelanggarnya diancam dengan sanksi hukuman penjara atau denda 240.000 malim atau bisa juga kedua-duanya. Dan tidak hanya pelaku poligami yang diancam, namun orang yang terlibat memudahkan terjadinya praktek poligami tersebut juga diancam dengan hukuman yang sama dengan pelakunya.

Secara diagonal, Tunisia ternyata telah beranjak paling depan dan sangat radikal dengan menutup pintu poligami serapat-rapatnya melalui pelarangan secara mutlak disertai sanksi hukum bagi pelanggarnya. Iran tampaknya juga telah bertindak liberal dengan memasukkan cukup banyak alasan yang tidak ada diatur dalam nash dan tidak pula disebutkan dalam berbagai mazhab fikih-sekalipun dalam alasan fasakh pernikahan-misalnya alasan kecanduan minumminuman keras dan hilangnya istri bagi kebolehan poligami. Lalu disusul Malaysia yang sedikit agak liberal di bawah Iran dengan alasan gila yang menimpa istri, kemudian Somalia yang agak moderat dengan alasan ada kebutuhan sosial yang sangat interpretable, dan Indonesia adalah yang paling moderat dengan alasan istri tidak dapat menjalankan kewajibannya sebagai istri yang memerlukan ijtihad yang sangat teliti dari hakim untuk membuktikannya dengan peluang 50 : 50, walaupun prinsip perkawinannya berdasarkan UU No.1/1974 adalah monogami.

\section{Penutup}

Dari pembahasan di atas, dapatlah diketahui bahwa lima negara yang menjadi fokus kajian dalam tulisan ini telah melakukan pembaharuan hukum keluarga yang cukup signifikan. Indonesia, Malaysia, Iran, dan Somalia tampaknya sepakat bagi kebolehan poligami, sedang Tunisia melarangnya secara mutlak. Terkait dengan masalah alasan poligami karena keadaan istri, maka empat negara selain Tunisia juga cenderung setuju dengan alasan istri tidak dapat berhubungan seksual. Mengenai alasan istri mendapat penyakit yang tidak dapat disembuhkan, hanya Somalia yang tidak menetapkan alasan tersebut. Begitu juga alasan karena istri mandul, hanya Iran yang tidak mencantumkannya sebagai alasan kebolehan poligami. Kemudian mengenai alasan karena istri terlibat tindak kriminal yang menyebabkannya dipenjara beberapa tahun, Iran dan Somalia mencantumkannya sebagai alasan hukum. Sedangkan alasan karena istri gila, hanya Malaysia yang mencantumkannya sebagai alasan poligami.

Dari penalaran beberapa alasan poligami yang ditetapkan oleh masing-masing negara tersebut, kiranya dapat menimbulkan dua interpretasi yang bisa jadi bertolak belakang atau bisa juga saling melengkapi. Pertama, tampaknya bias gender masih mewarnai corak fikih yang dianut dan dipahami oleh para ulama yang terlibat dalam pembuatan hukum keluarga Islam. Ini terlihat misalnya pada penyebutan alasan cacat yang sepihak pada wanita secara gamblang dan tak 
seimbang dengan penyebutan cacat pada pria.

Kedua, bisa juga dipahami bahwa penetapan alasan-alasan poligami karena keadaan istri tersebut untuk tetap menjaga keutuhan rumah tangga dan sekaligus menutup aib istri, menolong istri agar tetap terjamin kebutuhan hidupnya, serta menjaga tetap terjalinnya hubungan keluarga suami dan istri. Sebab kalau seandainya istri yang cacat atau tidak mampu lagi berhubungan seksual dicerai oleh suaminya, tentu akan menimbulkan banyak kecurigaan yang dapat membuka aib si istri dan bisa juga mempermalukan keluarganya. Begitu juga kalau si istri tidak punya penghasilan sedang ia mandul atau gila, tentu kalau suami menceraikannya maka si istri akan tersia-sia dan terancam kebutuhan hidupnya. Selain itu, stigma dan image negatif terhadap status janda cerai yang berkembang dalam anggapan masyarakat pada umumnya juga dapat membuat para wanita tersebut lebih tertekan dan tersiksa secara psikis.

Adapun metode yang umum digunakan untuk pembaharuan hukum keluarga di berbagai negara Muslim, lebih khusus untuk masalah alasan-alasan poligami karena keadaan istri di atas, tampaknya lebih dominan menggunakan metode extradoctrinal reform dan sedikit dengan intra-docrinal reform, itupun masing-masing dengan modifikasi dan tekanan yang berbeda-beda.

\section{Lampiran}

BAGAN ANALISA HORIZONTAL DAN DIAGONAL

Alasan-alasan Poligami Karena Keadaan Istri:

\begin{tabular}{|c|c|c|c|c|c|}
\hline No. & $\begin{array}{c}\text { N e g a r a } \\
\text { Alasan-alasan }\end{array}$ & I r a n & Malaysia & Somalia & Indonesia \\
\hline 01. & Seksual & $\checkmark$ & $\checkmark$ & & $\checkmark$ \\
\hline 02. & Penyakit & $\checkmark$ & $\checkmark$ & & $\checkmark$ \\
\hline 03. & Mandul & & $\checkmark$ & $\checkmark$ & $\checkmark$ \\
\hline 04. & Gi l a & & $\checkmark$ & & \\
\hline \multirow{2}{*}{05.} & \multirow{2}{*}{ Dipenjara } & Min. & & Lebih & \\
\hline & & 5 Th. & & 2 Th. & \\
\hline 06. & $\begin{array}{c}\text { Kecanduan } \\
\text { Miras, Judi dan } \\
\text { semacamnya }\end{array}$ & $\checkmark$ & & & \\
\hline 07. & $\begin{array}{c}\text { Meninggalkan } \\
\text { Keluarga Tanpa } \\
\text { Izin } \\
\end{array}$ & $\checkmark$ & & $\checkmark$ & \\
\hline 08. & $\mathrm{H}$ i l a n g & $\checkmark$ & & & \\
\hline 09. & $\begin{array}{l}\text { Kebutuhan } \\
\text { Sosial }\end{array}$ & & $\checkmark$ & & \\
\hline
\end{tabular}

Keterangan:

- Semakin rinci dan banyak alasan yang disebutkan, berarti semakin longgar dan besar peluang poligami

- Tunisia tidak dimasukkan dalam tabel karena melarang poligami secara mutlak

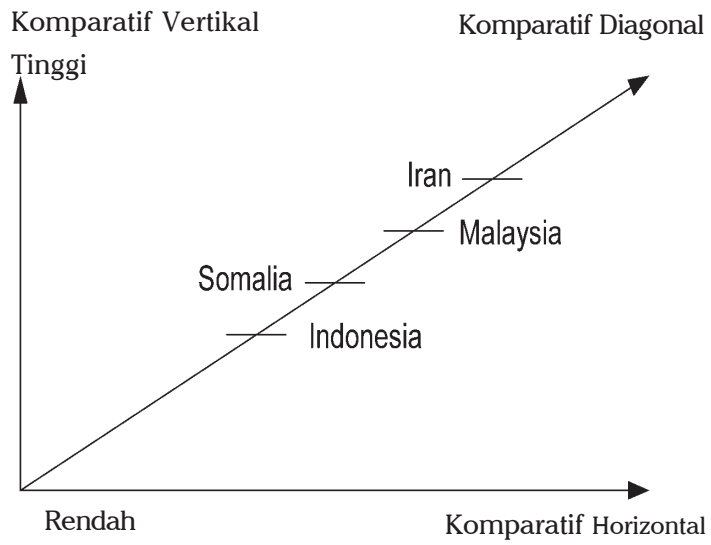

Keterangan: Secara vertikal, keberanjakan hukum keluarga kelima negara di atas dari kitab-kitab fikih mazhab cukup tinggi

\section{Pustaka Acuan}

Anderson, J.N.D., Law Reform in the Muslim World, London: University of London the Athlon press, 1976.

Anderson, J.N.D., "The Tunisian Law of Personal Status", dalam International and Comparative Law Quarterly, 7 April 1985.

Al-'Atthar, Abdul Nashir Taufiq, Poligami Ditinjau dari Segi Agama, Sosial, dan PerundangUndangan, alih bahasa Chadijah Nasution, Jakarta: Bulan Bintang, 1976, Cet. ke-1.

Bek, Muhammad al-Khudari, Tarikh al-Tasyri' alIslami, Kairo: maktab al-Tijariah Kubra, 1965.

Coulson, N.J., A History of Islamic Law, Edinburgh: Edinburgh University Press, 1994.

Engineer, Asghar Ali, Hak-hak Perempuan Dalam Islam, terj. Farid Wajidi dan Cici Farkha Assegaf, Yogyakarta: LSPPA \& CUSO, 1984.

Esposito, John L., Women in Muslim Family Law, Syracus: Syracus University Press, 1982.

Esposito, John L., The Oxford Encyclopaedia of Modern Islamic World, New York-Oxford: Oxford University Press, 1991, Jilid IV

Glasse, Cyrill, Ensiklopedi Islam, Jakarta: RajaGrafindo Persada, 1996, Cet. ke-1.

Gupta, Kiran, "Poligami Law Reform in Modern Status", dalam Islamic Law and Comparative Law, Vol. XIII, No. 2 Tahun 1992

al-Jasshas, Ahkam al-Qur'an, Beirut: Dâr al-Kitab 
al-Islamiyah, t.th.

Mahmood, Tahir, Family Law Reform in the Muslim World, Delhi: N.M Tripathi Pvt, 1972, Cet. ke-1

Mahmood, Tahir, Personal Law in Islamic Countries, New Delhi: Academy of Law and religion, 1987.

Mudzhar, Mohammad Atho, Membaca Geolombang Ijtihad Antara Tradisi dan Liberasi, Yogyakarta: Titian Ilahi Press, 1998.

Mughniyah, Muhammad Jawad, al-Fiqh 'Ala alMadzâhib al-Khamsah, (Beirut: Dâr al-Fikr, t. th.

Nasution, Khoiruddin, Status Wanita di Asia Tenggara: Studi Terhadap Perundang-undangan Perkawinan Muslim Kontemporer di Indonesia dan Malaysia, Leiden-Jakarta: INIS, 2002, Cet. ke-1

Sabiq, Sayyid, Fiqh al-Sunnah, Beirut: Dâr al-Fikr, t.t., Juz VI
Sayis, Muhammad Ali al-, Tafsir Ayat al-Ahkam, Kairo: Dâr al-Fikr, 1953, Jilid IV

Shabuni, Muhammad Ali al-, Rawâi' al-Bayân Tafsîr Ayat al-Ahkâm, (Beirut: Dar al-Fikr, t.t), Juz II

Shan'ani, Muhammad ibn Ismail al-Kahlani al-, Subul al-Salâm, Semarang: Toha Putra, t.th, Juz III

Syaltut, Mahmud dan M. Ali al-Sayis, Perbandingan Mazhab Dalam Masalah Fiqh, Alih bahasa: Ismuha, Jakarta: Bulan Bintang: 1993, Cet. ke-7 Thabari, Ibnu Jarir al-, Jami' al-Bayân fi Tafsîr alQur'ân, Beirut: Dar al-Fikr, 1958, Jilid VI

Tirmidzi, Sunan al-Tirmidzi, Beirut: Dâr al-Kutub al-Ilmiyyah, t.th.

Zuhrah, Muhammad Abu, Ushul al Fikr, Beirut: Dar al-Fikr, t.th. 